\title{
Geochemical studies on the color and chemical composition of Rainbow stone in Kita and Minami Daito Islands
}

\author{
Kiyoshi Kaneshima ${ }^{1}$, Hatsuo Taira ${ }^{1}$, Yasushi Kitano ${ }^{2}$, \\ Akira TAKaEsu ${ }^{3}$ and Seizen Agata ${ }^{4}$ \\ Department of Chemistry, College of Science, University of the Ryukyus, Okinawa 903-01 ${ }^{1}$, \\ Water Research Institute, Nagoya University, Nagoya $464^{2}$, \\ Futaba Gakuen, Tokyo $102^{3}$ and Naha Handicap School, Okinawa $902^{4}$, Japan
}

(Received May 14, 1984: Accepted August 28, 1984)

\begin{abstract}
Rainbow stone, or colored limestone consists of four portions which differ in its color and chemical composition. They are black colored portion due to manganese dioxide (micro-manganese nodules), reddish brown portion due to iron oxides, pale yellowish pink portion due to aluminosilicate and some other compounds, and white portion due to calcite and/or proto-dolomite. The color of Rainbow stone is controlled mainly by $\mathrm{Fe}_{2} \mathrm{O}_{3}$ and $\mathrm{MnO}_{2}$ contents. Elctron probe micro analyses (EPMA) clarify the existence of micro-manganese nodules in the black portion with iron oxides in its nucleus. Rhombohedral crystals of dolomite are observed wtih calcite. $\mathrm{NaCl}$ crystals, which are confirmed by X-ray diffraction analysis and EPMA, are incorporated into proto-dolomite almost regardless of its color. This shows that proto-dolomite on Daito Islands could have been formed through the evaporation of concentrated sea water.
\end{abstract}

\section{INTRODUCTION}

Some geochemical studies on major and minor chemical components and physical characteristics of limestones with different geological ages in Ryukyu Islands have been reported (Kaneshima, 1965; Kaneshima et al., 1973; Tokuyama et al., 1972).

Daito Islands which are nearly $400 \mathrm{~km}$ to the east of Okinawa Island, are made of carbonate and raised atolls. There are a few works on Daito limestone. Aoki (1934) outlined the geology of both islands. Takenaga $(1966,1972)$ observed the topography of Minami Daito Island and discussed the geological characteristics of Daito limestone. Kashima (1974, 1975) studied the mineralogical composition of acid insoluble residue of limestone on Minami Daito Island and discussed the dolomitization mechanism from sedimentary and petrological stand points. Ohde et al. (1978, 1981) determined some minor element concentrations in carbonates from Minami Daito Island by neutron activation analyses.
The colored limestone on Daito Islands is preserved in hard type of dolomite existing on the outer rim of the islands. Takenaga (1966) introduced this colored limestone as "Red Earth Pan" and observed conditions of its formation with its geological background.

Since the stripes of the colored limestone look like rainbow in appearance, it has been popularly called "Rainbow stone" and has been widely used for ornaments and trinkets. The colored limestone here is called Rainbow stone according to its popular name.

In relation to the color or carbonates, Kitano (1954) reported that the color changes variously according to $\mathrm{Fe}$ and $\mathrm{Mn}$ contents of carbonates deposited in hot springs. Tsubota and Kitano (1956) discussed the relation further and outlined it. They pointed out that some catalytic reaction of the surface of the above components would have taken place on the process to form various types of the colored limestone.

In the study of iron precipitates in hot spring deposits, Iwasaki et al. (1954) discussed 
the relation between color and chemical composition in comparison with laboratory works on systheses of various crystal forms of iron oxides and hydroxides. Accordingly, there is a positive relation between color and iron or manganese contents of hot spring deposits.

In this report, relations between color and some chemical constituents of limestone are discussed with a special note on the evolutional conditions of proto-dolomite on Daito Islands.

\section{EXPERIMENTAL}

Samples Rainbow stone samples were collected from both Kita and Minami Daito Islands. Minami Daito Island is located at $25^{\circ} 50^{\prime} \mathrm{N}$, $131^{\circ} 14^{\prime} \mathrm{E}$, about $400 \mathrm{~km}$ to the east of Okinawa Island. Kita Daito Island is located at $25^{\circ} 56^{\prime} \mathrm{N}$, $131^{\circ} 17^{\prime} \mathrm{E}$, about $12 \mathrm{~km}$ to the north of Minami Daito Island. The islands are surrounded by cliffs and are made of carbonates abundant in proto-dolomite.

The sampling sites on both islands are shown in Fig. 1. The Rainbow stone beds beatifully and forms a stratiform deposit with fine structure of different colors such as red, yellow, orange, reddish brown, dark brown, black and white. Rainbow stone is usually formed on the northern side of both islands.
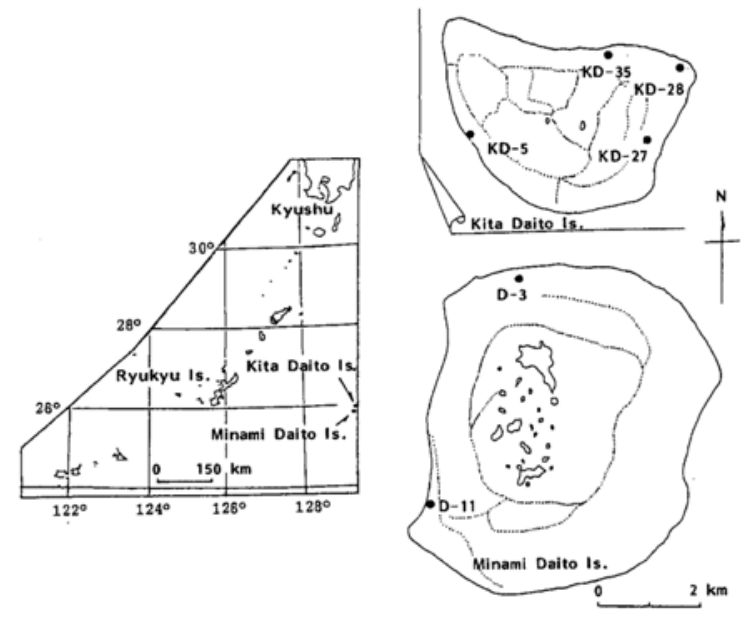

Fig. 1. Map of sampling stations.
Method Samples were crushed and separated into fractions of different colors. The separated samples were powdered. They were decomposed by hydrochloric and perchloric acid solution (Isono et al., 1968). Chemical components were then determined as follows: $\mathrm{SiO}_{2}$ by gravimetry, $\mathrm{CaO}, \mathrm{MgO}, \mathrm{Fe}_{2} \mathrm{O}_{3}$ and $\mathrm{Al}_{2} \mathrm{O}_{3}$ by titration with EDTA, minor elements such as $\mathrm{Mn}$ and $\mathrm{Na}$ by atomic absorption spectrometry and $\mathrm{Cl}$ by spectrophotometric method (Iwasaki et al., 1956).

Mineralogical composition was determined by X-ray diffration analysis. Electron probe micro analysis (EPMA) was carried out at Central Laboratory of Dowa Kogyo Co. under the following conditions: 1) Cut and slice the samples, 2) fix them on Epoxy resin holders, 3) abrasion by emery paper and diamond paste of 3,1 and $0.25 \mu \mathrm{m}$ particle sizes, 4) evaporation of carbon on the surface of the sample for 2 minutes in a $5 \times 10^{-5}$ torr vacuum chamber to a thickness of about $180 \AA$. EPMA was then carried out with the use of $\mathrm{LiF}$ crystal fixed at $\mathrm{Fe} \mathrm{K} \alpha_{1}$, X-ray wavelength to detect iron in the sample. Critical X-ray patterns were taken for elements which have shown the X-ray images. EPMA was introduced to KD-28B of black, D-3E of reddish brown, D3D of brown, $\mathrm{D}-3 \mathrm{H}$ of yellowish brown and KD-28A of white colored samples.

\section{Results AND Discussion}

Chemical composition Table 1 gives the mineralogical composition and the color for 7 and 11 samples collected from Kita and Minami Daito Islands, respectively. Table 2 gives the analytical results for some chemical constituents which are closely related to the color of Rainbow stone and the formation of protodolomite. Figures 2, 3, 4 and 6 show the Xray photographic images. Figure 5 shows the relationship between relative concentration ratios and $\mathrm{Cl}$ content of various carbonate samples in Ryukyu Islands. Figure 7 shows the $\mathrm{X}$-ray diffraction patterns to clarify the existence of $\mathrm{NaCl}$ crystals. 
Table 1 shows that mineralogical composition is different between Kita and Minami Daito Islands. A major mineral component in samples from Minami Daito Island is protodolomite whereas that in samples from Kita Daito Island sometimes is $\mathrm{Mg}$-calcite containing

Table 1. Mineralogical composition and color of Rainbow stone

\begin{tabular}{l|rrrrl}
\hline $\begin{array}{c}\text { Sample } \\
\text { No. }\end{array}$ & $\begin{array}{c}\text { Dol. } \\
(\%)\end{array}$ & $\begin{array}{c}\text { Cal. } \\
(\%)\end{array}$ & $\begin{array}{c}\text { Mg-cal. } \\
(\%)\end{array}$ & $\begin{array}{c}\text { Arag. } \\
(\%)\end{array}$ & \multicolumn{1}{c}{ Color } \\
\hline KD-28B & 20 & 77 & - & - & grayish black \\
KD-28A & 100 & - & - & - & white \\
KD-27 & 93 & 4 & - & - & grayish black \\
KD-5 & 53 & 42 & - & - & pale yellowish orange \\
KD-35A & 13 & - & 60 & - & yellowish brown \\
KD-35B & 34 & - & 50 & - & dull yellowish orange \\
KD-35C & 16 & - & 50 & 19 & yellowish orange \\
D-3A & 48 & 45 & - & - & yellowish brown \\
D-3B & 95 & - & - & - & light brown \\
D-3C & 99 & - & - & - & brown (burnt sienna) \\
D-3D & 95 & - & - & - & brown (burnt sienna) \\
D-3E & 96 & - & - & - & brown (coffee) \\
D-3F & 94 & - & - & - & brown (coffee) \\
D-3G & 93 & - & - & - & light brown \\
D-3H & 95 & - & - & - & yellowish brown \\
D-3I & 90 & 7 & - & - & yellowish brown \\
D-11A & 91 & 4 & 4 & - & grayish white \\
D-11B & - & 99 & - & - & pale yellowish orange \\
\hline
\end{tabular}

Dol. $=$ Dolomite, Cal. $=$ Calcite, Mg-cal. $=$ Magnesian calcite, Arag. $=$ Aragonite . a relatively small amount of proto-dolomite. Likewise, chemical and mineralogical composition of Rainbow stones differs considerably between two islands even if they appear visually the same. This may imply that the formation process of Rainbow stones somewhat differs from each other on both islands.

The description of colors of Rainbow stones is based on both Munsell's system and color description system in Japan expressed by three categories such as hue, value and chroma (Hoshino, 1957). The hue consists of 11 steps and that of Rainbow stones varies between 0 and 7 . The value of the color is usually described as 11 steps from black(0) to white(10). According to the Japanese system, however, it is divided into 21 steps. The value of Rainbow stones lie between 11 and 19. The chroma of the color is expressed by 11 steps from colorless $(0)$ such as black and white to perfect pure color(10). The chroma of Rainbow stones varies between 0 and 4.

The Rainbow stone can be grouped into 4 types according to chemical compositions and color levels. The first group, as is shown in Table 2, exhibits the deepest blackish color such

Table 2. Chemical composition and color of Rainbow stone from Kita and Minami Daito Islands

\begin{tabular}{|c|c|c|c|c|c|c|c|c|c|}
\hline $\begin{array}{l}\text { Sample } \\
\text { No. }\end{array}$ & $\begin{array}{l}\mathrm{SiO}_{2} \\
(\%) \\
\end{array}$ & $\begin{array}{c}\mathrm{Fe}_{2} \mathrm{O}_{3} \\
(\%)\end{array}$ & $\begin{array}{c}\mathrm{Al}_{2} \mathrm{O}_{3} \\
(\%)\end{array}$ & $\begin{array}{l}\mathrm{MgO} \\
(\%)\end{array}$ & $\begin{array}{l}\mathrm{CaO} \\
(\%)\end{array}$ & $\begin{array}{c}\mathrm{Na} \\
(\mathrm{ppm})\end{array}$ & $\begin{array}{c}\mathrm{Cl} \\
(\mathrm{ppm})\end{array}$ & $\begin{array}{c}\mathrm{Mn} \\
(\mathrm{ppm})\end{array}$ & $\mathrm{H}-\mathrm{Color}$ \\
\hline KD-28B & 0.02 & 0.12 & 0.76 & 6.24 & 47.00 & 2500 & 3570 & 23000 & Grayish black \\
\hline KD-27 & 0.03 & 0.04 & 0.33 & 17.91 & 33.46 & 3200 & 4030 & 9300 & $0-11-0$ \\
\hline D-3-F & 0.07 & 3.28 & 0.41 & 18.38 & 31.30 & 2000 & 2230 & 7300 & \multirow{2}{*}{$\begin{array}{l}\text { Brown coffee } \\
4-13-3\end{array}$} \\
\hline D-3-E & 0.05 & 3.32 & 0.31 & 18.42 & 32.15 & 1200 & 1680 & 3400 & \\
\hline D-3-D & 0.08 & 3.76 & 0.25 & 18.16 & 32.07 & 1100 & 1390 & 2000 & $\begin{array}{l}\text { Brown } \\
4-14-4\end{array}$ \\
\hline D-3-B & 0.02 & 3.64 & 0.36 & 17.96 & 31.90 & 1200 & 1560 & 230 & \multirow{3}{*}{$\begin{array}{l}\text { Light Brown } \\
4-16-4\end{array}$} \\
\hline D-3-G & 0.10 & 4.80 & 0.38 & 17.13 & 32.19 & 1800 & 2060 & 130 & \\
\hline D-3-H & 0.03 & 4.04 & 0.20 & 17.56 & 32.43 & 840 & 1040 & 1300 & \\
\hline D-3-A & 0.84 & 2.97 & 0.64 & 9.87 & 40.50 & 3100 & 4050 & 80 & \multirow{2}{*}{$\begin{array}{l}\text { Brilliant Yellow Orange } \\
7-18+4\end{array}$} \\
\hline D-3-I & 0.42 & 2.10 & 0.20 & 17.43 & 33.93 & 720 & 770 & 87 & \\
\hline D-3-C & 0.02 & 0.39 & 0.17 & 18.79 & 33.47 & 1700 & 2220 & 550 & $\begin{array}{l}\text { Pale Yellow Orange } \\
6-19-2\end{array}$ \\
\hline KD-35A & 11.18 & 2.01 & 4.47 & 9.12 & 32.99 & 2400 & 2740 & 730 & \multirow{4}{*}{$\begin{array}{l}\text { Pale Yellow Pink } \\
7-19-3\end{array}$} \\
\hline KD-35B & 6.00 & 1.64 & 4.06 & 11.64 & 33.43 & 3300 & 3480 & 120 & \\
\hline KD-36C & 7.67 & 1.20 & 2.32 & 7.28 & 39.31 & 2200 & 2490 & 540 & \\
\hline KD-5 & 4.31 & 0.64 & 0.92 & 10.04 & 41.55 & 550 & 400 & 120 & \\
\hline D-11B & 0.15 & 0.06 & 0.11 & 1.65 & 53.81 & 270 & 220 & 90 & \multirow{3}{*}{$\begin{array}{l}\text { Grayish White } \\
0-19-0\end{array}$} \\
\hline D-11A & 0.07 & 0.04 & 0.13 & 17.98 & 34.53 & 960 & 870 & 340 & \\
\hline KD-28A & 0.10 & 0.01 & 0.12 & 19.71 & 32.97 & 480 & 410 & 67 & \\
\hline
\end{tabular}

$H=$ Hue,$V=$ Value, $C=$ Chroma . 
as grayish black, brown coffee and brown burnt sienna. This group of samples have very high $\mathrm{Mn}$ content. Along with the increase in $\mathrm{Mn}$ content, the color deepens toward blackish color, while brown color increases along with decreasing $\mathrm{Mn}$ and increasing $\mathrm{Fe}$ contents. Samples grouped in this category are KD-27 and KD-28 from Kita Daito Island and D-3F, D-3D from Minami Daito Island.

The second group with light brown, bright yellowish orange and pale yellowish orange, has the highest $\mathrm{Fe}_{2} \mathrm{O}_{3}$ content. $\mathrm{Fe}$ and $\mathrm{Mn}$ contents mainly control the color in this group. High $\mathrm{Fe}$ and low Mn contnets give rise to light brown color and color change toward pale yellowish orange according to the decrease in $\mathrm{Fe}$ content. The second group is found only on Minami Daito Island. The Mn content is relatively low as compared with that of the first group.

The third group, KD-35 with pale yellowish pink color, is collected only from Kita Daito Island and shows high $\mathrm{SiO}_{2}$ and $\mathrm{Al}_{2} \mathrm{O}_{3}$ contents. High positive correlations between these contents may imply that some aluminosilicate materials such as clay minerals would have been incorporated into Rainbow stone in the formation processes.

The fourth group, D-11 and KD-28 with grayish white color, are poor in the above chemical components and consist of almost pure calcite and/or proto-dolomite.

The atomic ratio of $\mathrm{Fe}$ to $\mathrm{Fe}+\mathrm{Mn}$ also governs the color of Rainbow stone. The high value of the color in the first group, 11 to 14 , depends on the high atomic ratio of $\mathrm{Mn}$ to $\mathrm{Fe}+$ Mn, i.e., 0.5 to $73.3 \%$. Tsubota and Kitano (1956) reported that various colors of carbonate deposits in hot springs can be explained by the combination of $\mathrm{Fe}_{2} \mathrm{O}_{3}$ and $\mathrm{MnO}_{2}$ contents, and the value of the color decreases significantly beyond $0.5 \%$ of atomic ratios of $\mathrm{Mn} /(\mathrm{Fe}+\mathrm{Mn})$. This agrees well with the values for Rainbow stone. The second group gives atomic ratios of $0.03-0.4 \%$, except $1.99 \%$ for D-3. This may cause high values, 16 to 19 , for the color of Rainbow stone. Tsubota and Kitano (1956) pointed out that the increase in the atomic ratio of less than $0.5 \%$ region may cause the increase in color value. In the case of D-3, the color value did not become low owing to the extremely low $\mathrm{Fe}_{2} \mathrm{O}_{3}$ content of $0.39 \%$.

EPMA - KD-28B, black The composition image of fine structure superimposed on line profiles and simple $\mathrm{K} \alpha_{1}, \mathrm{X}$-ray images for $\mathrm{Mn}$ and $\mathrm{Fe}$ are shown in Figs. 2a, 2b, 2c and 2d, respectively.

Figure 2 clearly shows that $\mathrm{Fe}$ is surrounded by $\mathrm{Mn}$ in some micro-nodule inclusions. This shows that iron oxides and/or hydroxides might have been precipitated first as nuclides of the nodules and the Mn was then precipitated on it to form $\mathrm{MnO}_{2}$ which could have been formed through the catalytic action of iron hydroxides as pointed out by Sung and Morgan (1981). This may be illustrated by terrestrial ferromanganese nodules in small size (Taira et al., 1981). EPMA and microphotographic observations on a sliced sample of a black colored portion show the existence of Mn of nodule type. This indicates that the black portion of Rainbow stone is made of micro-manganese nodules of $\mathrm{MnO}_{2}$ form.

EPMA - D-3H, yellowish brown Composition images and $\mathrm{Ca}, \mathrm{Mg}$ and $\mathrm{Fe} \mathrm{K} \alpha_{1} \mathrm{X}$-ray images for yellowish brown sample of $\mathrm{D}-3 \mathrm{H}$ are shown in Figs. 3a, 3b, 3c and 3d, respectively.

Figure $3 \mathrm{a}$ shows that some squarish crystals are found around rhombic and/or cubic crystals, and central two portions and the right side of upper corner on the picture look like rhombic and cubic caves. The image for $\mathrm{Ca}$ is not observed in these portions of the cave-like shade. As it is seen from Figs. $3 b$ and $3 c$ that the $\mathrm{Ca}$ content seems to increase on outer portions of the caves whereas the $\mathrm{Mg}$ content seems to decrease in high $\mathrm{Ca}$ content portions. This may show that $\mathrm{Ca}$ coexists with $\mathrm{Mg}$ around caves through dolomite formation on nucleate substances such as calcite existing in the vicinity. Figure 3d shows that $\mathrm{Fe}$ coexists mainly with $\mathrm{Mg}$ although some reasonable amounts of $\mathrm{Fe}$ are observed in rhombic and cubic crystals with almost no $\mathrm{Ca}$ and $\mathrm{Mg}$.

EPMA - D-3E, reddish brown Sample D- 
$3 \mathrm{E}$ consists of reddish brown and white portions forming latteral stripes. Composition image and $\mathrm{Fe} \mathrm{K} \alpha_{1} \quad \mathrm{X}$-ray images for the boundary area between reddish brown and relatively white portions are shown in Figs. $4 a$ and $4 b$, respec- tively. Reddish brown portion in Fig. $4 \mathrm{a}$ is shown on the left side and white portion on the right side.

It is apparent from Fig. $4 \mathrm{~b}$ that $\mathrm{Fe}$ is highly concentrated in the reddish brown portion (left

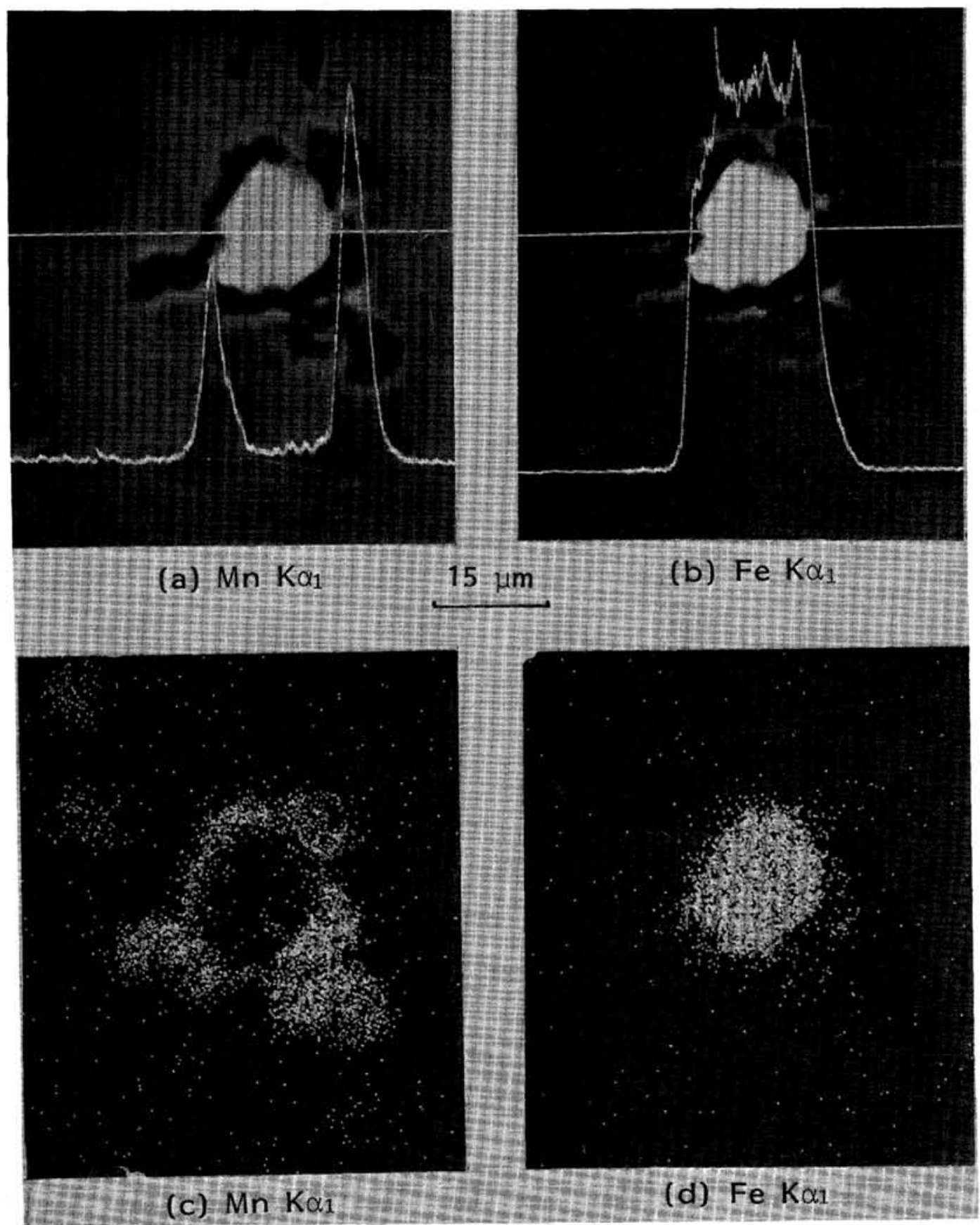

Fig. 2. EPMA for Mn and $\mathrm{Fe}$ in sample KD-28B (black colored portion) $(\times 1200)$. (a) Composition image and line profile for $\mathrm{Mn} \mathrm{K \alpha}, \mathrm{X}$-ray, (b) Composition image and line profile for $\mathrm{Fe} K \alpha, X$-ray, (c) $\mathrm{Mn} \mathrm{K \alpha}, \mathrm{X}$-ray image, (d) $\mathrm{Fe} \mathrm{K} \alpha, \mathrm{X}$-ray image. 
side) as compared with the white portion (right side). This shows that the reddish brown color is caused mainly by the existence of iron oxides. In order to make it clear, a leaching experiment with dilute perchloric acid was carried out on the reddish brown portion, leading to the separation of hematite. This suggests the existence of $\mathrm{Fe}^{3+}$ as $\mathrm{Fe}_{2} \mathrm{O}_{3}$ rather than $\mathrm{Fe}^{2+}$. $\mathrm{Fe}^{3+}$ are considered to be dispersed homogeneously in protodolomite and calcite. Reddish color is deepened by the decrease in $\mathrm{MnO}_{2}$ content.

High $\mathrm{Na}$ and $\mathrm{Cl}$ contents As is seen in Table 2, Na content of Rainbow stone shows the con- centration range of 480 to $3,320 \mathrm{ppm}$ on the average of $1,400 \pm 400 \mathrm{ppm}$, which is 10 times as high as that in Riukiu limestone with the average of $140 \pm 20 \mathrm{ppm}$. Chloride content lies in the range of 220 to $4,050 \mathrm{ppm}$ on the average of $1,950 \pm 790 \mathrm{ppm}$, and is roughly 20 times more concentrated than in Riukiu limestone of $79 \pm 30 \mathrm{ppm}$, slightly more than that in calcareous marine sediments of $1,210 \mathrm{ppm}$ and several times more than that in corals of 380 ppm on the average.

Some geochemical studies on limestone and proto-dolomite on Minami Daito Island were

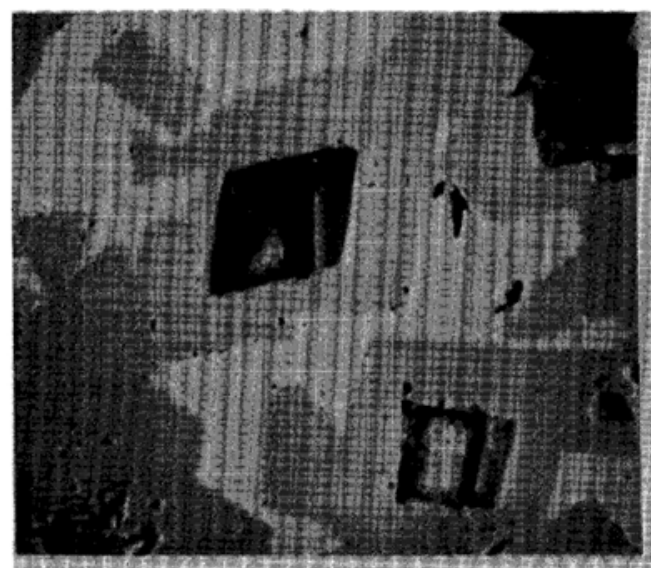

(a) $\mathrm{D}-3 \mathrm{H}$

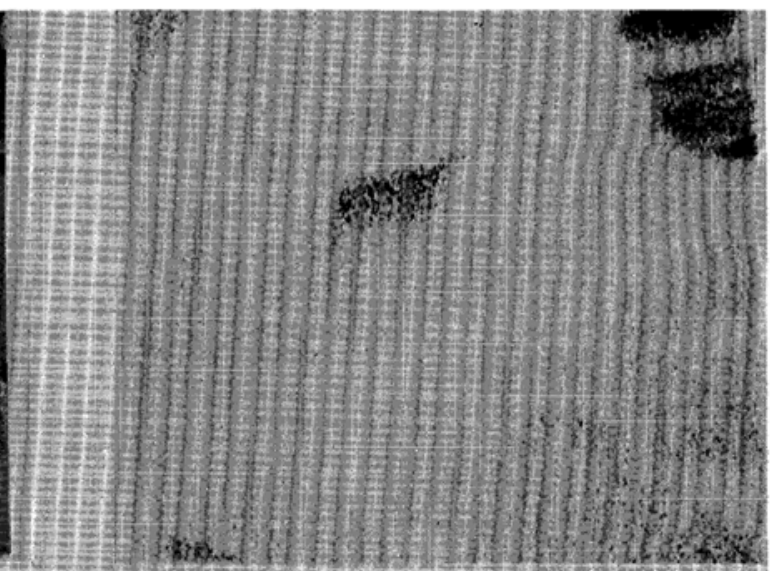

(b) Ca Ko1

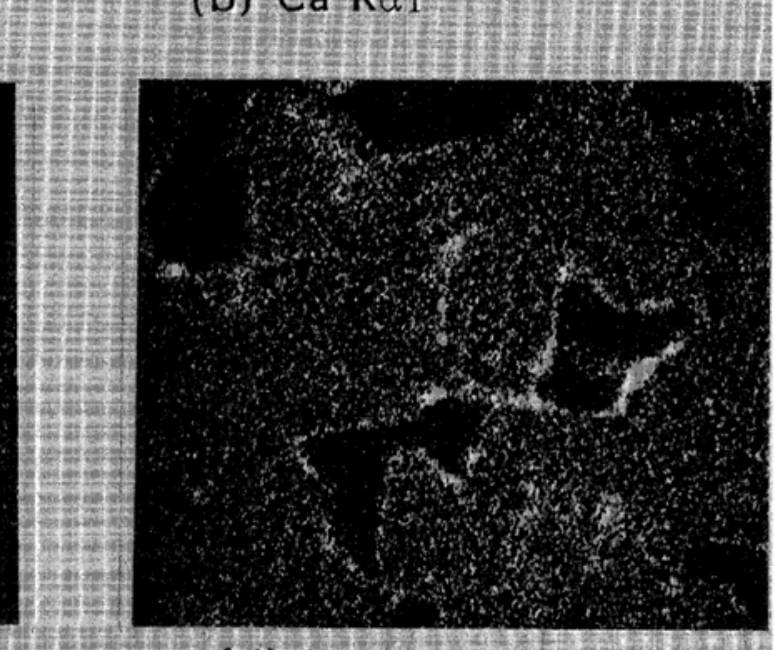

(d) $\mathrm{Fe} \mathrm{K \alpha i}$ (c) $M g$ Kol

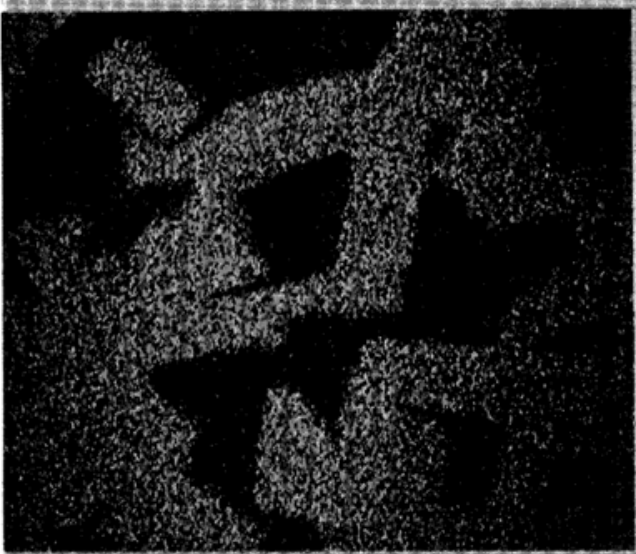
215.

Fig. 3. EPMA for Ca, $\mathrm{Mg}$ and $\mathrm{Fe}$ in sample D-3H (yellowish brown) (X600). (a) Composition image, (b) Ca $\mathrm{K \alpha}$, $X$-ray image, (c) $M g K \alpha, X$-ray image, (d) $\mathrm{Fe} K \alpha, X$-ray image. 


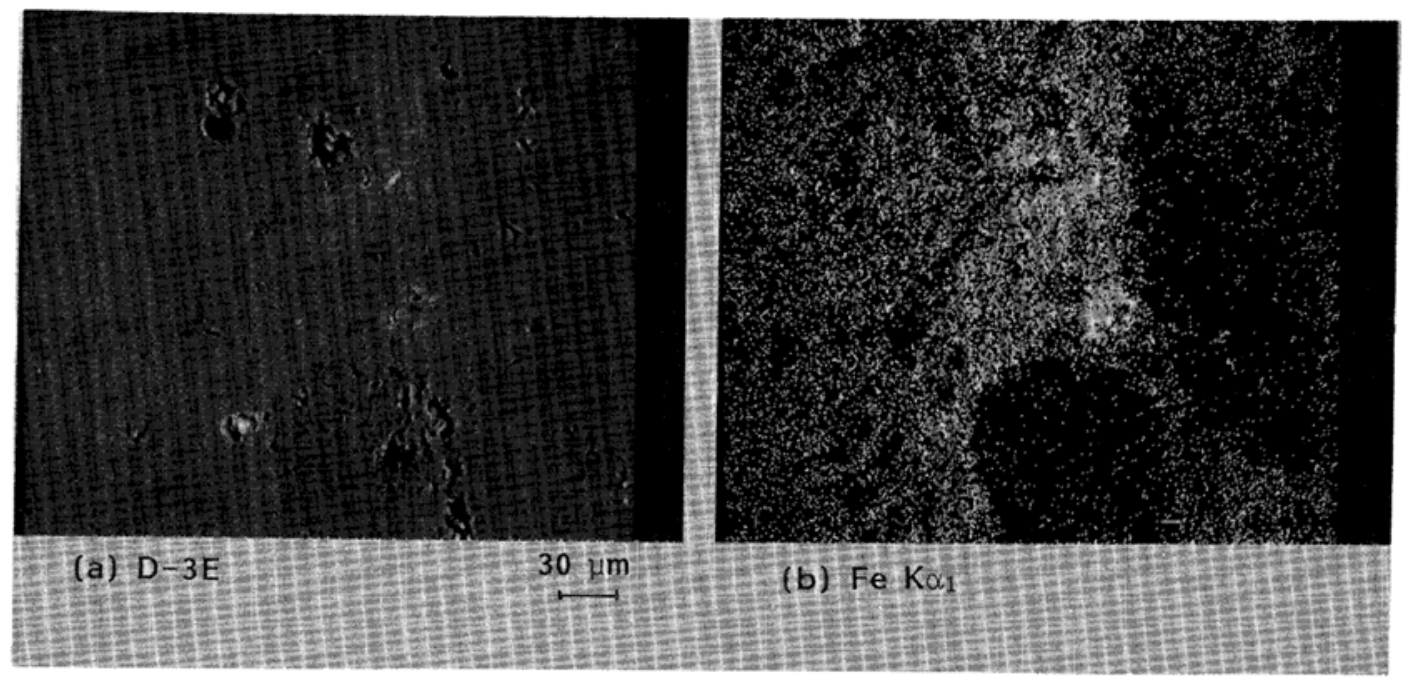

Fig. 4. EPMA for Fe in sample D-3E (boundary area between reddish brown and white portions) ( $\times 300)$. (a) Composition image, (b) $\mathrm{Fe} \mathrm{K \alpha}, \mathrm{X}$-ray image.

reported by Ohde and Kitano (1981). They reported that $\mathrm{Cl}$ content of reef samples ranges from 41 to $2,300 \mathrm{ppm}$ on an average of $690 \pm$ $340 \mathrm{ppm}$. The values are comparable with those in Rainbow stone.

The change of $\mathrm{Na} / \mathrm{Cl}$ concentration ratio in samples with respect to that in sea water is plotted against chloride content in Fig. 5 for Rainbow stone, coral and marine sediments.

Figure 5 shows that relative concentration ratios in Rainbow stone are almost constant

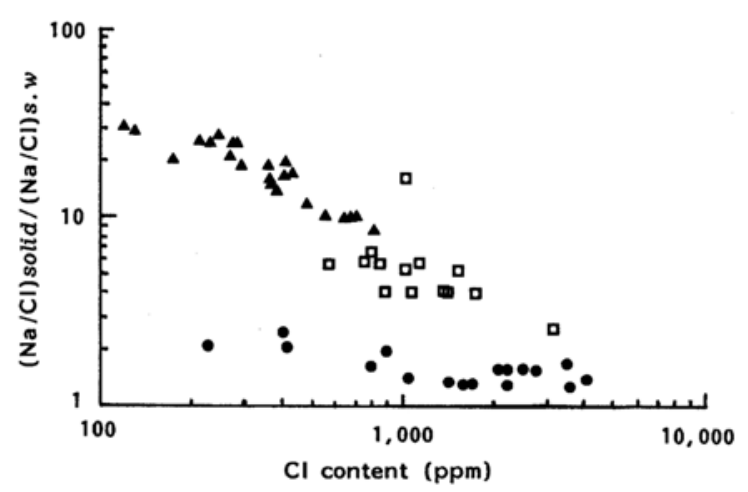

Fig. 5. Relationship between relative concentration ratios, $(\mathrm{Na} / \mathrm{Cl})$ solid $/(\mathrm{Na} / \mathrm{Cl}) \mathrm{s} . \mathrm{w}$, and $\mathrm{Cl}$ content. $(\mathrm{Na} / \mathrm{Cl})$ solid and $(\mathrm{Na} / \mathrm{Cl})$ s.w denote $\mathrm{Na} / \mathrm{Cl}$ ratios in sample and in sea water, respectively. Solid cricles $(\bullet)$ are for Rainbow stone, solid triangles (4) are for corals and open squares (ㅁ) are for marine seiments. at about 1.6 inspite of the large change in chloride content. This may support the consideration that most parts of $\mathrm{Na}$ and $\mathrm{Cl}$ would have been taken into Rainbow stone as $\mathrm{NaCl}$.

Contrary, the relative concentration ratio changes significantly from 8 to 30 in individual coral samples, showing lower values toward higher chloride content. The values for marine sediments locate in between the above two cases. The result for coral may corroborate the discussion by Tokuyama (1974) that major portion of $\mathrm{Na}$ would be taken into coral not only as $\mathrm{NaCl}$ but also as $\mathrm{Na}_{2} \mathrm{SO}_{4}$ as well. The values in Fig. 5 as a whole, however, show an exponential decrease with the exponential increase in chloride content throughout various carbonate samples.

The high positive correlation between $\mathrm{Na}$ and $\mathrm{Cl}$ contents also indicates that most of $\mathrm{Na}$ and $\mathrm{Cl}$ exist as $\mathrm{NaCl}$ in Rainbow stone, even though some part of $\mathrm{Na}$ may form other compounds with negative ions such as $\mathrm{SO}_{4}{ }^{2-}$ and $\mathrm{F}^{-}$ since $\mathrm{Na}$ content is always slightly higher than $\mathrm{Cl}$ content. The extent of $\mathrm{Na}$ content exceeding $\mathrm{NaCl}$ composition in marine sediments and proto-dolomite from the central part of Okinawa Island becomes greater along with the increase in $\mathrm{Cl}$ content than that in Rainbow stone. 


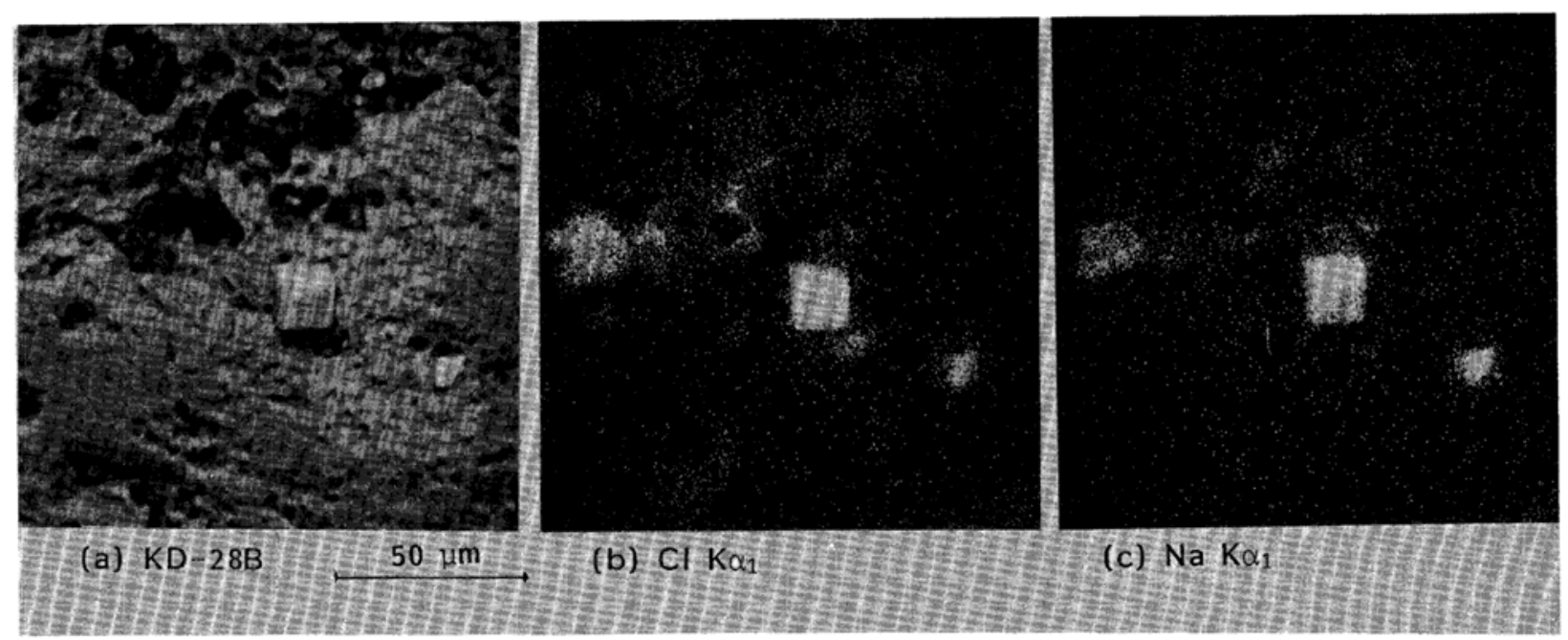

Fig. 6. EPMA for $\mathrm{Cl}$ and $\mathrm{Na}$ in sample $\mathrm{KD}-28 \mathrm{~B}$ (black portion (X600). (a) Composition image, (B) Cl $\mathrm{K \alpha}, \mathrm{X}$-ray image, (c) $N a \mathrm{K \alpha}$, X-ray image.

Existence of $\mathrm{NaCl}$ crystals Composition image and $\mathrm{Na}$ and $\mathrm{Cl} \mathrm{K} \alpha_{1}$ X-ray images for $\mathrm{KD}$ 28B (black portion) are shown in Figs. 6a, 6b and $6 \mathrm{c}$, respectively.

Cubic type of composition images seen in central portion in Fig. 6a clearly indicates the existence of $\mathrm{NaCl}$ crystals, which is also confirmed from Figs. $6 \mathrm{~b}$ and $6 \mathrm{c}$. The photographic scale of Fig. $6 \mathrm{a}$ indicates that $\mathrm{NaCl}$ crystals have a side of about $19 \mu \mathrm{m}$. $\mathrm{NaCl}$ crystals is also observed in KD-28A (white portion) and also in samples collected from Minami Daito Island such as D-3D (brown) and D-3H (yellowish). Cave-like shades, which are seen in D-3H (Fig. $3 \mathrm{a})$, could be estimated to be as remains caused by the dissolution of $\mathrm{NaCl}$ crystals into water in the process of making sliced samples for EPMA measurements.

To make clearer the existence of $\mathrm{NaCl}$ crystals, X-ray diffraction patterns for $\mathrm{NaCl}$ crystals in proto-dolomite were taken. Figure 7 shows peaks at $2 \theta=31.8^{\circ}$ and $45.5^{\circ}$ which denote the existence of $\mathrm{NaCl}$ crystals. This may lead to the following estimation; Proto-dolomite could be formed with $\mathrm{NaCl}$ crystals as nuclei from concentrated sea water system with sufficient $\mathrm{MgCl}_{2}$ concentration. In regard to the formation of dolomite, Alderman et al. (1957) reported that dolomite is formed in a shallow inlet of the sea and in a saline lake in Australia.
Masuzawa and Kitano (1983) reported that $\mathrm{Ca}$ and $\mathrm{Mg}$ with a molar ratio of nearly unity are removed from interstitial water in core samples

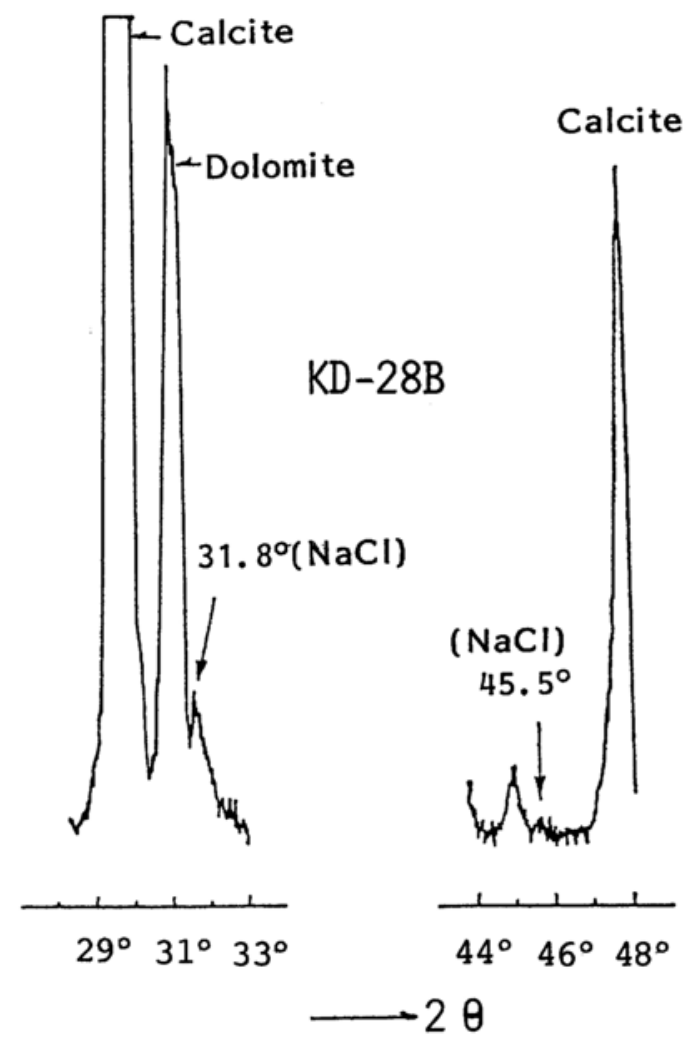

Fig. 7. X-ray diffraction patterns for sample KD-28B (black portion). 
from the Japan Sea probably to form protodolomite. The reports are suggestive of the evolutional conditions of proto-dolomite formation on Daito Islands.

It is a distinguishing trait of Rainbow stone to have such a low relative concentration ratio and very high $\mathrm{Na}$ and $\mathrm{Cl}$ contents of $\mathrm{NaCl}$ composition as compared with other carbonate samples in the Ryukyu Islands. These facts, particularly the existence of $\mathrm{NaCl}$ crystals in Rainbow stone, may give an important feature and are very suggestive of the evolutional environments of dolomite formation on Daito Islands.

Acknowledgements-We thank Mr. R. Nishihama, Minami Daito Island, for his help in collecting samples. Dr. M. Suematsu at Central Laboratory of Dowa Kogyo Co. helped us in electron probe micro analyses. Thanks are also due to Mr. T. Oomori in our Laboratory for his help in X-ray measurements. Professor K. Shimabukuro at Department of Biology, University of the Ryukyus, provided every facility for microscopic studies.

\section{REFERENCES}

Alderman, A. R., Catherine, H. and Skinner, W. (1957) Dolomite sedimentation in the south-east of South Australia. Am. J. Sci. 255, 561-567.

Aoki, R. (1934) Geological and topographical observations of Kita and Minami Daito Jima. J. Geol. Soc. Tokyo 41, 341-343 (Japanese).

Hoshino, S. (1957) Color scheme and its adjustment. Maruzen, Tokyo (Japanese).

Isono, K., Fujinuki, T., Nagai, S. and Kaneko, H. (1968) Total analysis of limestone and dolomite. Chem. Anal. Geol. Surv. Jpn., No. 40, 92p. (Japanese).

Iwasaki, I., Fukutomi, G. and Tarutani, T. (1954) Geochemical studies of hot spring deposit. Ferruginous deposit. Part I. Nippon Kagaku Zasshi 75, 282-286 (Japanese).

Iwasaki, I., Utsumi, S. Hagino, K. and Ozawa, T. (1956) A new specrophotometric method for the determination of small amounts of chloride using the mercuric thiocyanate method. Bull. Chem. Soc. Jpn. 29, 860-864.

Kaneshima, K. (1965) Comparative studies on limestone on Ryukyu Islands. Bull. Arts \& Sci. Div., the Ryukyu Univ. (Math. \& Nat. Sci.) 8, 23-54 (Japanese).

Kaneshima, K., Taira, H., Tokuyama, A. and Oomori, T. (1973) The study on the Riukiu Limestone and associated materials. Bull. Science \& Engineering Div., Univ. the Ryukyus (Math. \& Nat. Sci.) 16, 134161.

Kashima, N. (1974) Insoluble residues from the Daito Limestone of Minami Daito-jima. Mem. Ehime Univ., Sci., Ser. D. (Earth Sci.) 7, 79-88 (Japanese).

Kashima, N. (1975) A note on the Daito Limestone of Minamidaitojima with special concern to its dolomitization. Mem. Ehime Univ., Sci., Ser. D (Earth Sci.) 7, 95-101 (Japanese).

Kitano, Y. (1954) Chemical compositions of calcium carbonates deposited from hot spring. Nippon Kagaku Zasshi 75, 125-129 (Japanese).

Masuzawa, T. and Kitano, Y. (1983) Interstitial water chemistry in deep-sea sediments from the Japan Sea. J. Oceanogr. Soc. Jpn. 39, 171-184.

Ohde, S., Ohta, N. and Tomura, K. (1978) Determination of trace element in carbonates by instrumental neutron activation analysis. J. Radioanal. Chem. 42, 159-167.

Ohde, S. and Kitano, Y. (1981) Protodolomite in Daito-jima, Okinawa. Geochem. J. 15, 199-207.

Sung, W. and Morgan, J. J. (1981) Oxidative removal of $\mathrm{Mn}$ (II) from solution catalyzed by the $\gamma-\mathrm{FeOOH}$ (lepidocrocite) surface. Geochim. Cosmochim. Acta 45, 2337-2383.

Taira, H., Kitano and Kaneshima, K. (1981) Terrestrial ferro-manganese nodules formed in limestone areas of the Ryukyu Islands. Part I. Major and minor constituents of terrestrial ferro-manganese nodules. Geochem. J. 15, 69-80.

Takenaga, K. (1966) Shore feature of Minami Daitojima, Okinawa. Chiri Kagaku 5, 1-22 (Japanese).

Takenaga, K. (1972) Caves at Minami Daito-jima, Okinawa and their topographical significance. Japan Caving 4, 57-65 (Japanese).

Tokuyama, A., Kitano, Y. and Kaneshima, K. (1972) Geochemical behavior of chemical species in the processes of limestone formation. Part I. Chemical composition of corals and limestone in the Ryukyu Islands. Geochem. J. 6, 83-92.

Tokuyama, A. (1974) $\quad \mathrm{Na}^{+}$and $\mathrm{SO}_{4}^{-}$contents in carbonate samples. Annual Meeting Geochem. Soc. Japan, Abst. B1 5, 97 (Japanese).

Tsubota, H. and Kitano, Y. (1956) Color of carbonate deposits formed in hot springs. Nippon Kagaku Zasshi 77, 901-905 (Japanese). 